\title{
A Case of the Hamartoma of Middle Ear Presenting with the Aplasia of Ipsilateral Internal Carotid Artery
}

\author{
Sangjun Kim ${ }^{1} \mathbb{D}$, Min Gyoung Pak ${ }^{2}$, and Sung Wook Jeong ${ }^{1} \mathbb{D}$ \\ ${ }^{1}$ Departments of Otolaryngology-Head and Neck Surgery, ${ }^{2}$ Pathology, College of Medicine, Dong-A University, Busan, Korea
}

\author{
내경동맥 무형성증을 가진 소아 환자에서 발견된 중이 과오종 1예 \\ 김상준 ${ }^{1} \cdot$ 박민경 $^{2} \cdot$ 정성욱 ${ }^{1}$ \\ 동아대학교 의과대학 이비인후과학교실, ${ }^{1}$ 병리학교실 ${ }^{2}$
}

\author{
Received December 1, 2020 \\ Revised March 19,2021 \\ Accepted April 12, 2021 \\ Address for correspondence \\ Sung Wook Jeong, MD, PhD \\ Department of Otorhinolaryngology- \\ Head and Neck Surgery, \\ College of Medicine, \\ Dong-A University, \\ 26 Daesingongwon-ro, Seo-gu, \\ Busan 49201, Korea \\ Tel $+82-51-240-5428$ \\ Fax $+82-51-253-0712$ \\ E-maildau_su@naver.com
}

\begin{abstract}
Hamartoma is a benign congenital tumor made of an abnormal mixture of normal tissues. It is a kind of developmental anomaly, in which the tissues are arranged with an excess growth of one or more of its components. Hamartoma is usually found in the lung, hypothalamus, and colon, but very rarely found in the head and neck areas. Symptoms are caused by the tumor tissue pressing against other tissues or organs. Surgical removal is the treatment modality of choice for hamartomas causing symptoms. The aplasia of unilateral internal carotid artery (ICA) is a rare congenital anomaly. ICA aplasia can cause structural change of the middle ear space. A 5 year-old female patient was presented with large hamartoma in the middle ear and the aplasia of the ipsilateral ICA. The mass was successfully removed without any complications. Authors report this case with a brief literature review.
\end{abstract}

Korean J Otorhinolaryngol-Head Neck Surg 2021;64(8):599-603

Key Words Hamartoma · Internal carotid artery diseases · Middle ear.

\section{서 론}

과오종은 하나 또는 그 이상의 정상 세포 성분이 증식하여 혼합된 양성 종양이다. ${ }^{1-3)}$ 과오종은 폐, 간, 신장, 비장에 주로 발생하며, ${ }^{4,5)}$ 두경부 영역에서의 발생은 드물다. 국내에서 보 고된 두경부 과오종은 비강, ()ㅣ인두, 혀, ()ㅜ개편도, ${ }^{4)}$ 후두 ${ }^{5)}$ 에서 발생하였으며, 중이에서 발생한 과오종은 보고된 바 없 다. 중이 과오종은 전 세계적으로 3 예가 보고되었을 정도로 매우 드물다. ${ }^{9-11)}$

일측 내경동맥 무형성증은 유병률이 $0.01 \%$ 로 매우 드물게 발생하는 선천적 혈관 기형이다. ${ }^{12)}$ 일측 내경동맥 무형성증이 있더라도 반대편 내경동맥의 앞교통동맥 겉순환에 의해 동

This is an Open Access article distributed under the terms of the Creative Commons Attribution Non-Commercial License (https://creativecommons.org/licenses/by-nc/4.0) which permits unrestricted non-commercial use, distribution, and reproduction in any medium, provided the original work is properly cited.
측 뇌실질에 혈액이 공급되어 대부분 무증상이다. 하지만 내 경동맥 무형성증 환자들은 뇌동맥류와 일과성 뇌허혈 발작의 발생률이 증가하는 것으로 보고되었다. ${ }^{13)}$ 내경동맥은 중고실 의 전벽을 형성하므로 내경동맥이 결손된 경우에는 중고실 구조의 변형이 초래될 수 있다. 저자들은 일측 내경동맥 무형 성증을 가진 아동의 동측 중이에 발생한 과오종을 치험하였 기에 문헌 고찰과 함께 보고하는 바이다.

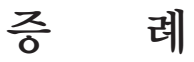

4세 10 개월 나이의 여아가 우측 중이의 종물에 대한 진료 를 위해 내원하였다. 아동은 1년 전부터 반복적으로 발생하는 우측 삼출성 중이염으로 거주지 인근 의원의 진료를 받던 중 중이 종물이 의심되어 본원으로 전원되었다. 이내시경 검사 에서 우측 고막의 중심부와 하방에 고막 전체 면적의 약 $2 / 3$ 
를 차지하는 타원 형태의 백색 종물이 관찰되었다(Fig. 1). 순 음청력검사에서 기도 청력(6분법 평균)은 우측 $35 \mathrm{~dB} \mathrm{HL}$, 좌측 $12 \mathrm{~dB} \mathrm{HL}$ 이었다. 환아가 차폐 검사를 수행하지 못해 골도청력검사는 시행하지 않았다. 이내시경 검사 소견에 근거 하여 중이 진주종을 의심하고 측두골 전산화단층촬영을 시 행하였다.

측두골 전산화단층촬영에서 우측 중고실, 하고실 전체와 이관의 입구부를 침범한 연조직 밀도의 병변이 관찰되었고

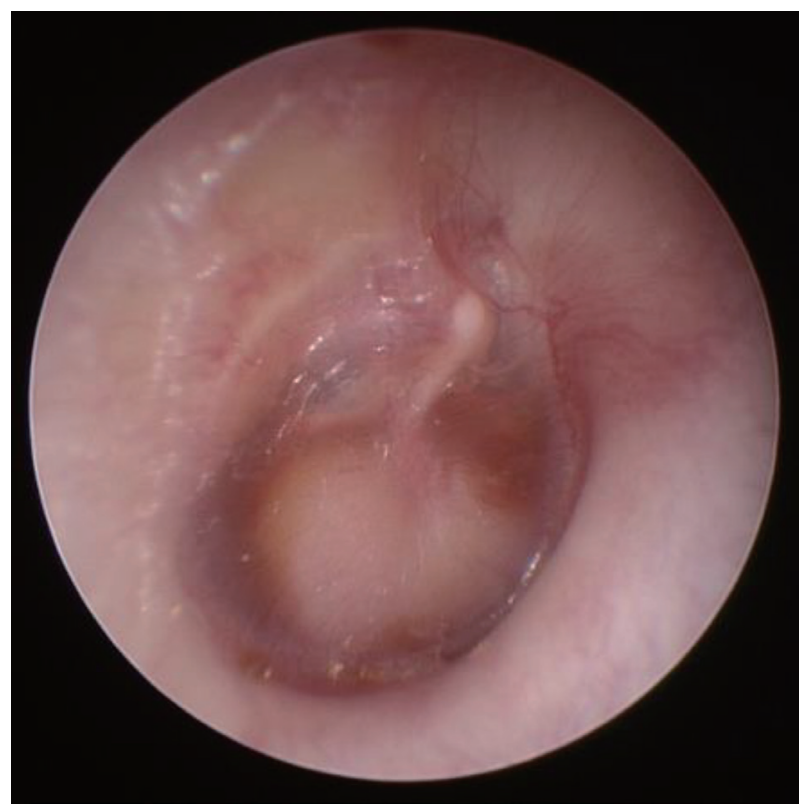

Fig. 1. Otoscopic finding that shows a whitish mass medial to right tympanic membrane.
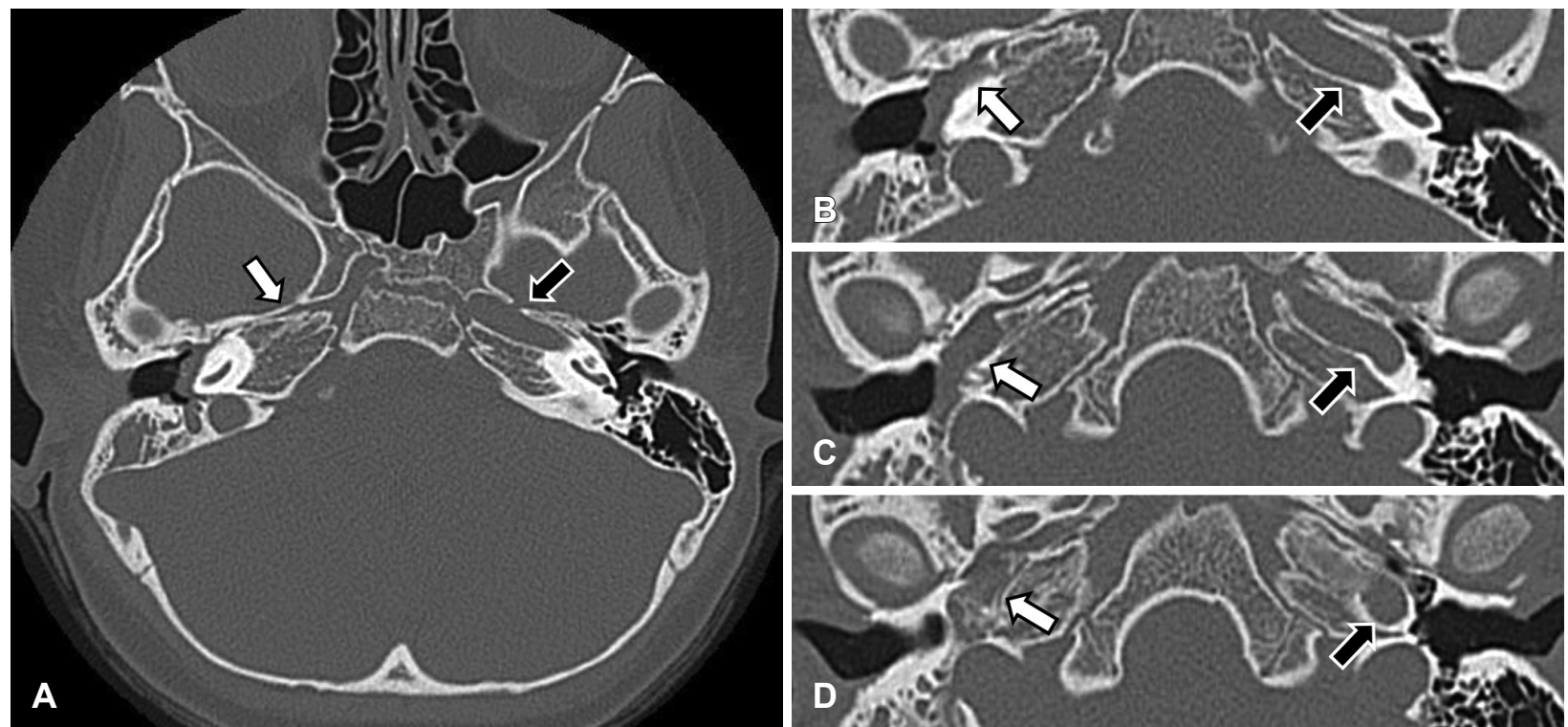

Fig. 2. The images of temporal bone CT. Axial images at the level of skull base are presented from superior (A) to inferior (D). The images show an absence of ICA at right side (white arrow) and an presence of normal ICA at left side (black arrow). Consecutive axial images from (B) to (D) show the soft tissue density lesion at right middle ear occupying the space where ICA should have been. ICA: internal carotid artery. 


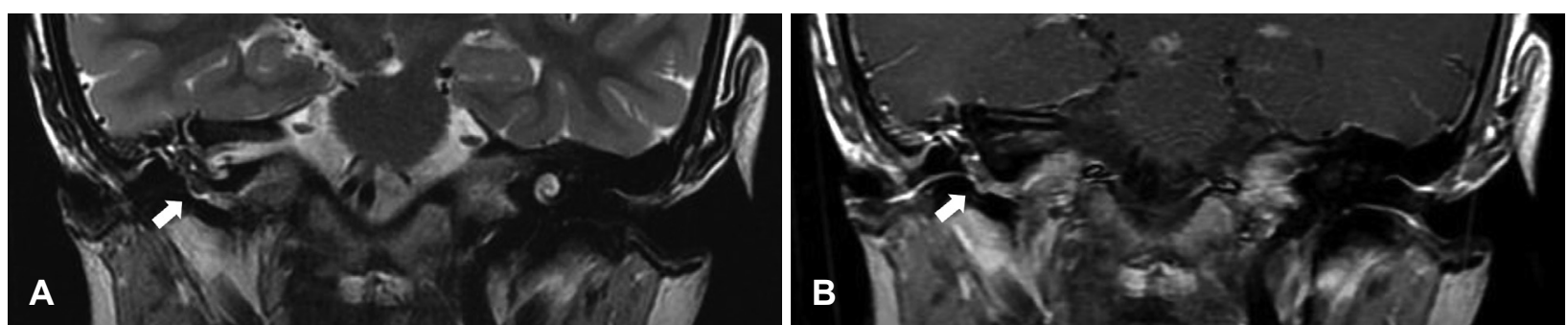

Fig. 3. MR images. T2-weighted image (A) shows a low signal intensity (arrow). Gadolinium enhanced T1-weighted image (B) shows an enhancing lesion (arrow).

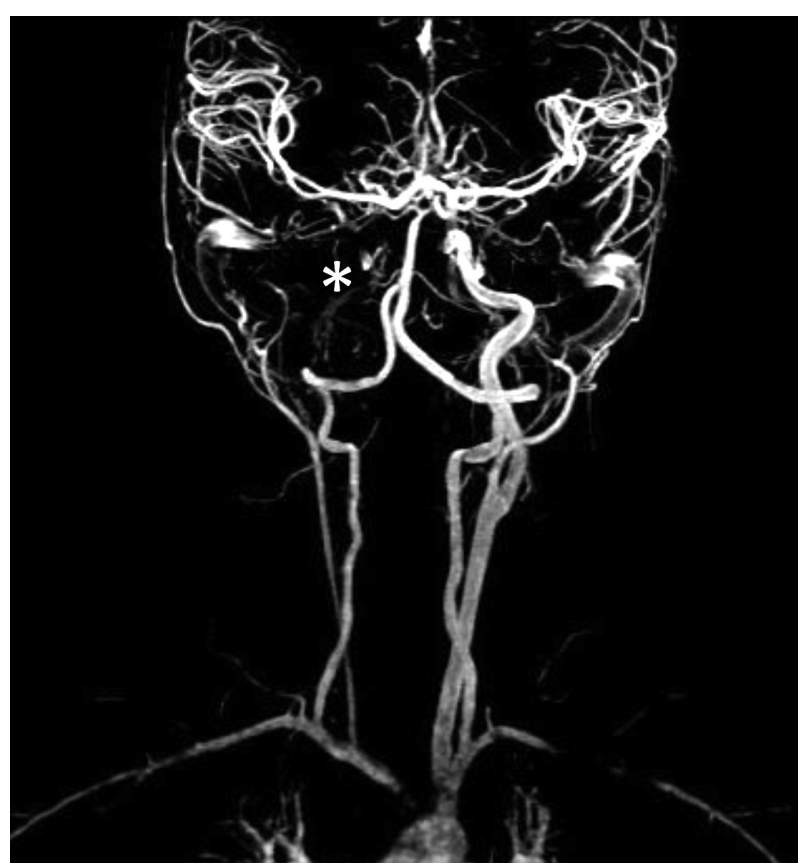

Fig. 4. The image of MR angiography. The right internal cervical artery (asterisk) is absent but ipsilateral anterior cerebral artery and middle cerebral artery are supplied by anterior communicating artery.

있었으나 이소골의 미란은 없었다. 침골-등골 관절을 분리하 여 침골을 제거하고 고막긴장건(tensor tympani tendon)을 자른 후 고실외이도 피판을 전방으로 완전히 밀어서 외이도 전벽에 닿도록 함으로써, 종물을 향한 시야와 종물을 제거할 작업 공간을 확보하였다. 종물은 전방 중고실(anterior mesotympanum)의 가장 깊은 부위에서 기시하여 중고실과 하 고실로 자라 나온 양상이었다. 특이한 점은 내경동맥 무형성 증으로 인해 전방 중고실이 전방으로 넓고 깊게 형성되어 있 었으며, 깊게 형성된 전방 중고실의 가장 전방 부위에서부터 종물이 기시하고 있었다. 수술 현미경 시야를 통해 종물의 상 당 부분을 제거하였으나, 종물이 기시한 전방 중고실의 가장 전방 부위는 수술 현미경 시야로는 접근되지 않아, $70^{\circ}$ 내시 경과 내시경 중이 수술 기구를 이용하여 전방 중고실에 위치 한 종물을 완전제거하였다. 종물 제거 과정에서 고막과 고실
륜의 결손이 발생하여, 측두근막을 이용하여 외면이식 고실 성형술을 시행하고 수술을 마쳤다. 수술 후 합병증은 없었으 며, 수술 이틀 후 퇴원하였다.

병리조직검사에서 종물은 정상 침샘 조직과 평활근, 지방 세포, 말초신경 조직으로 구성되어 있었다. 면역조직화학염색 에서 침샘 조직은 pan- $\mathrm{CK}$, 평활근 조직은 smooth muscle actin, 말초신경 조직은 S100에 양성을 보여 과오종으로 확 진하였다(Fig. 6). 수술 후 6개월 동안의 추적 관찰에서 고막 은 치유되었고 내시경 진찰 소견상 재발 소견은 없으며, 추후 이소골 성형술을 시행할 예정이다.

\section{고 찰}

과오종은 신체 모든 부위에서 발생할 수 있다. 과오종 자체 에 의한 증상은 드물기 때문에 신체검사와 영상검사에서 우 연히 발견되는 경우가 대부분이고, 드물게 증상이 있는 경우 에는 종괴에 의한 압박증상이 나타날 수 있다. ${ }^{5)}$ 과오종의 유 병률은 폐에서 발생한 경우를 제외하고는 밝혀져 있지 않다. 폐 과오종의 유병률은 약 $0.25 \%$ 로 모든 폐 종양의 약 $8 \%$ 를 차지한다. ${ }^{14}$ 과오종의 조직병리적 특징은 연골과 혈관, 지방의 간엽조직과 상피, 분비선등의 상피성 조직이 혼재되고 특정 조직의 과도한 증식이 관찰되며 세포 이형성 또는 악성 변화 는 극히 드물다. ${ }^{5)}$ 과오종은 완전절제가 가장 좋은 치료 방법 이며, 완전절제한 경우 재발은 알려진 바가 없다. ${ }^{14}$

중이 과오종은 발생 부위에 존재하는 정상 조직의 증식이 라는 점에서 기형종(teratoma), 유피종(dermoid)과 감별하여 야 한다. 기형종은 외배엽, 중배엽, 내배엽의 3 배엽 모두에서 유래한 조직을 포함하고, 유피종은 외배엽과 중배엽에서 유래 한 조직의 낭성 종괴라는 점에서 과오종과 구분된다. 또한 과 오종은 분리종(choristoma)과도 감별하여야 하는데, 분리종 은 정상적으로 해당부위에서 발견될 수 없는 조직이 증식하 는 종양으로, 정상위치에서 정상적으로 존재하는 세포 중 일 부가 비정상적인 성장과 배열을 보이는 과오종과 구분된다. 본 증례의 중이 종물은 평활근, 지방세포, 말초신경, 침샘 조 

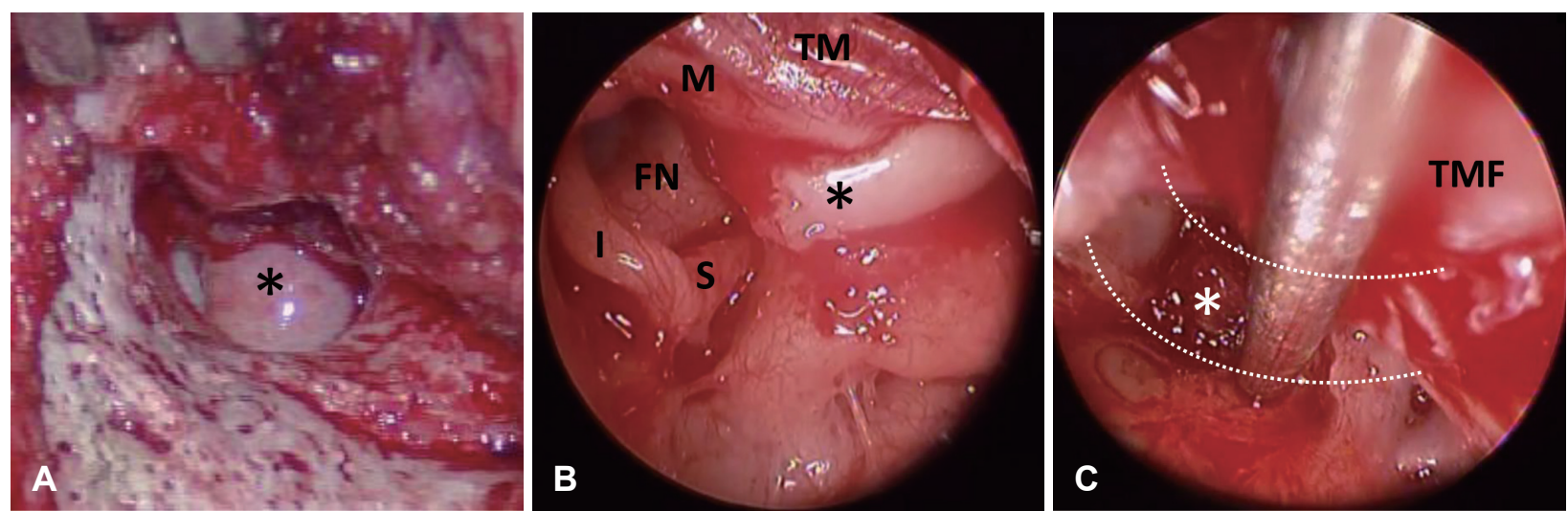

Fig. 5. The surgical findings. (A) The microscopic view of right middle ear after elevating tympanomeatal flap shows large mass occupying mesotympanum and hypotympanum (asterisk). (B) The $30^{\circ}$ endoscopic view after removing the posterior half of the mass. Anterior half of the mass (asterisk) is remained. Ossicular continuity is intact though long process of incus is bent. (C) The $70^{\circ} \mathrm{endoscopic} \mathrm{view}$ showing anterior mesotympanum after further removing the mass. Tympanomeatal flap was pushed forward fully to be attached to anterior wall of external auditory canal after removing incus and cutting tensor tympani tendon. The remaining mass (asterisk) was attached tightly to anterior wall of enlarged anterior mesotympanum where ICA should had been. The last part of the mass is being removed using Fish dissector. The two dashed lines indicate the imaginary ICA. M: malleus, I: incus, S: stapes, FN: facial nerve, TM: tympanic membrane, TMF: tympanomeatal flap, ICA: internal carotid artery.
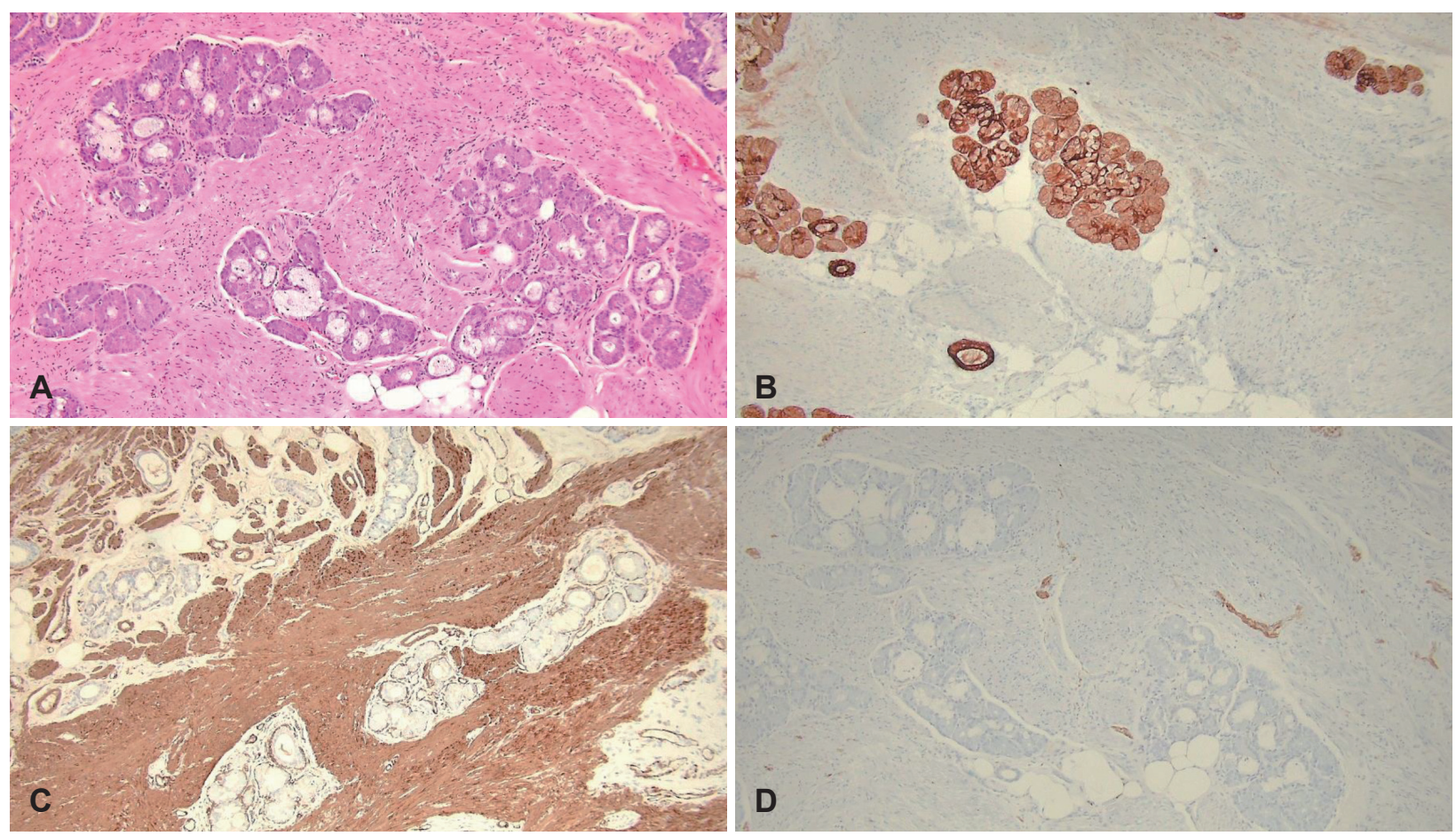

Fig. 6. The microscopic findings of the tumor. (A) The tumor was mainly composed of benign salivary gland, which were separated by smooth muscle bundles. The mature fat tissue and peripheral nerve bundles were interspersed (hematoxylin and eosin stain, $\times 100$ magnification). (B) Immunohistochemical staining for pan-CK highlights the salivary gland (pan-CK, $\times 100$ magnification). (C) The smooth muscle bundles were positive for SMA (SMA, $\times 100$ magnification). (D) The peripheral nerve bundles showed positive immunoreactivity for $\mathrm{S} 100$ (S100, $\times 100$ magnification). SMA: smooth muscle actin.

직으로 구성되어 과오종으로 진단되었다. 비록 중이에 정상적 으로 존재하지 않는 침샘 조직이 포함되었으나, 종물 전체가 침샘조직 단독으로 구성되지 않았고, 지방, 근육, 신경 조직 등 정상적으로 중이강에 존재하는 조직 성분이 종물의 대부 분을 구성하였기 때문에 병리학적으로 과오종으로 진단되었 다. 또한 중배엽과 외배엽에서 기원한 조직 성분만으로 구성

\section{되어 기형종도 배제할 수 있었다.}

일측 내경동맥 무형성증은 매우 드문 선천성 혈관 기형으 로 유병률은 약 $0.01 \%$ 이다. 일측 내경동맥 무형성증 환자는 대부분 무증상인데, 이는 윌리스 고리(Willis circle)의 겉순환 으로 인해 결손된 내경동맥의 동측 대뇌반구의 모든 뇌실질 에 정상적으로 혈액 공급이 이루어지기 때문이다. ${ }^{12)}$ 하지만 
뇌동맥류 발생 가능성과 뇌혈류의 부전으로 인한 일과성 뇌 허혈 발작의 발병률이 증가한다. ${ }^{13)}$ 내경동맥 무형성증 환자의 뇌동맥류 유병률은 25\% 43\%로 혈관기형이 없는 환자의 유 병률 2\% 4\%보다 크게 높은 것으로 조사된 바 있다. ${ }^{12,13)}$

본 증례는 일측 내경동맥 무형성증을 가진 환자의 동측 중 이에 발생한 과오종을 치험한 것으로 전 세계적으로 이와 같 은 증례는 보고된 바가 없다. 본 증례 환자는 내경동맥 무형 성증으로 인한 뇌혈관 관련 문제는 없었으나, 내경동맥의 결 손으로 인해 전방 전고실이 매우 깊게 형성되어 있었고, 이 공간의 가장 깊숙한 부위에서 과오종이 발생하여 시야 확보 와 종물 제거에 어려움이 있었다.

정상 고막을 가진 소아에서 중이 종양이 의심될 때 선천성 진주종, 콜레스테롤 육아종, 안면신경종, 횡문근육종, 육종, 지방종, 기형종 등을 감별해야 한다. ${ }^{15)}$ 소아에서 중이 내에 백 색에 가까운 종물이 보일 경우 선천성 진주종의 가능성이 가 장 높으나 본 증례에서 보듯이 과오종의 가능성도 염두에 둘 필요가 있다는 점과, 내경동맥의 결손은 뇌동맥류를 포함한 뇌혈관 문제 외에도 중이 공간의 변형을 초래할 수 있다는 두 가지 임상적 의의가 있어 본 증례를 보고하는 바이다.

\section{Acknowledgments}

None.

\section{Author Contribution}

Conceptualization: Sung Wook Jeong. Data curation: Sangjun Kim. Methodology: Sung Wook Jeong. Visualization: Min Gyoung Pak. Writing — original draft: Sangjun Kim. Writing—review \& editing: Sung Wook Jeong.

\section{ORCIDs}

Sung Wook Jeong https://orcid.org/0000-0002-5445-1638
Sangjun Kim

\author{
https://orcid.org/0000-0002-6025-6775
}

\section{REFERENCES}

1) Shara KA, al-Muhana AA, al-Shennawy M. Hamartomatous tonsillar polyp. J Laryngol Otol. 1991 Dec;105(12):1089-90.

2) Yigitbasi OG, Guler G, Ozturk F, Guney E. Glandular hamartoma of the larynx. Int J Pediatr Otorhinolaryngol 2002;65(2):163-6.

3) Buckmire RA, Kwon TK. Bilateral obstructing laryngeal epithelial adenomatous hamartomas. Arch Otolaryngol Head Neck Surg 2005;131(3):259-61.

4) Na HG, Bae CH, Kim YD, Song SY. A case of hamartoma originated from the palatine tonsil. Korean J Otorhinolaryngol-Head Neck Surg 2011;54(10):731-3.

5) Lee MJ, Kim JY, Shim HK, Kim MR. A case of hamartoma of the subglottis. Korean J Otorhinolaryngol-Head Neck Surg 2018;61(7): 370-3.

6) Lee HK, Cho KJ, Jung SH, Kim NS. A case of fibro-osseous hamartoma originated from nasal cavity. Korean J OtorhinolaryngolHead Neck Surg 2008;51(5):495-8.

7) Kim KM, Kwon SH, Park HS, Kang MJ. A case of mixed epithelial and mesenchymal hamartoma of nasopharynx. Korean J Otorhinolaryngol-Head Neck Surg 2012;55(3):191-3.

8) Park JB. A rare case of hamartoma of the tongue. Korean J Otorhinolaryngol-Head Neck Surg 1975;18(1):57-9.

9) Baget S, François A, Andrieu-Guitrancourt J, Marie JP, Dehesdin D. Hamartoma of the middle ear: A case study. Int J Pediatr Otorhinolaryngol 2003;67(3):287-91.

10) Eichel BS, Hallberg OE. Hamartoma of the middle ear and eustachian tube. Report of a case. Laryngoscope 1966;76(11):1810-5.

11) Mahataphongse VP, Conner GH. Middle ear hamartoma. Trans Pa Acad Ophthalmol Otolaryngol 1977;30(1):49-51.

12) Shukla SK, Parashar S, Saxena S. Congenital absence of unilateral internal carotid artery with an intracerebral aneurysm. Asian J Neurosurg 2018;13(3):774-6.

13) Lee JH, Oh CW, Lee SH, Han DH. Aplasia of the internal carotid artery. Acta Neurochir (Wien) 2003;145(2):117-25; discussion 125.

14) Wang T, Liu Y. Outcomes of surgical treatments of pulmonary hamartoma. J Cancer Res Ther 2016;12(Suppl):116-9.

15) Park SI, Park MH, Ahn J, Chung WH. A case of lipoma in the middle ear. Korean J Otorhinolaryngol-Head Neck Surg 2019;62(7):404-8. 